\title{
IMPLIKASI YURIDIS TERHADAP PEJABAT PEMBUAT AKTA TANAH PENERIMA KUASA MENYETOR UANG PAJAK PENGHASILAN/ BEA PEROLEHAN HAK ATAS TANAH DAN BANGUNAN DARI WAJIB PAJAK
}

\author{
Arifuddin, Hanif Nur Widhiyanti, Hariyanto Susilo \\ Program Studi Magister KenotariatanFakultas Hukum Universitas Brawijaya \\ Jl. M.T. Haryono 169 Malang \\ email: ariffudin2015@gmail.com
}

\begin{abstract}
Based on the background, the formulation of the problem is: How is the legality of the act of receiving tax receipts by Land Titles Registrar (PPAT) as a public official and How juridical implications of PPAT who receive tax and income tax of Acquisition of Land and Building Rights(PPHTB) from taxpayers. The method used to examine these issues is normative legal research using a statute approach to examine legislation relating to legal issues under review. Based on the results of the research, the results obtained that the legality of accepting tax receipts by PPAT as public officials actually still does not exist, in other words has not established a definite rule that regulates the act of receiving tax receipts by PPAT. Then about juridical implication to PPAT which accept tax day income tax and BPHTB from taxpayer is even though the act have not have legal legality but its implementation still included in legitimate category because that action depart from habit that have been accepted and accepted by society. As long as there is no rule of law to realize the legality of this act then as long as it is also this habit will continue, although there is no guarantee of legal protection for this act but as long as it does not cause harm to anyone then considered not a problem.
\end{abstract}

Keywords: Land Titles Registrar, income tax, Acquisition of Land and Building Rights, taxpayer, endorsee

\begin{abstract}
Abstrak: Tujuan penulisan ini adalah mendeskripsikan legalitas perbuatan menerima kuasa menyetor pajak oleh Pejabat Pembuat Akta Tanah (PPAT) selaku pejabat umum dan implikasi yuridis terhadap PPAT yang menerima penitipan Pajak Penghasilan (PPh) dan Bea Perolehan Hak Atas Tanah dan Bangunan (BPHTB) dari wajib pajak. Metode yang digunakan untuk meneliti permasalahan tersebut adalah penelitian hukum normatif dengan menggunakan pendekatan perundang-undangan (statute approach) untuk menelaah peraturan perundang - undangan yang terkait dengan isu hukum yang sedang dikaji. Legalitas perbuatan menerima kuasa menyetor pajak oleh PPAT selaku pejabat publik sesungguhnya masih belum ada, dengan kata lain belum dibentuk suatu aturan pasti yang mengatur tentang perbuatan menerima kuasa menyetor pajak oleh PPAT. Kemudian tentangImplikasi yuridis terhadap PPAT yang menerima penitipan pajak PPh dan BPHTB dari wajib pajak adalah meskipun perbuatan tersebut belum memiliki legalitas hukum namun pelaksanaannya masih termasuk dalam kategori sah sebab perbuatan tersebut berangkat dari kebiasaan yang berlaku selama ini dan diterima oleh masyarakat. Selama belum ada aturan hukum untuk mewujudkan legalitas dari perbuatan ini maka selama itu pula kebiasaan ini akan terus berlanjut, walaupun tidak ada jaminan perlindungan hukum atas perbuatan ini tetapi selama tidak menimbulkan kerugian bagi siapapun maka dianggap tidak masalah.
\end{abstract}

Kata Kunci: pejabat pembuat akta tanah, pajak penghasilan, Bea Perolehan Hak Atas Tanah dan Bangunan,wajib pajak, penerima kuasa

Setiap perolehan hak atas tanah dan/atau bangunan, mewajibkan pihak yang menerima untuk membayar Bea Perolehan Hak Atas Tanah dan Bangunan (BPHTB). Untuk perolehan hak yang terjadi melalui jual beli, maka pajak dikenakan kepada kedua belah pihak baik penjual maupun 
pembeli. Kepada penjual dikenakan Pajak Penghasilan (PPh) dan kepada pembeli dikenakan Bea Perolehan Hak Atas Tanah dan Bangunan (BPHTB) yang besarnya dihitung berdasarkan harga perolehan hak atau Nilai Perolehan Objek Pajak (NPOP). Dalam bahasa sehari-hari, NPOP bisa juga diartikan sebagai nilai transaksi atau nilai kesepakatan harga antara penjual dan pembeli. Terdapat faktor lain yang menjadi dasar penghitungan BPHTB yaitu Nilai Jual Objek Pajak (NJOP) yang merupakan nilai yang tertera dalam Surat Pemberitahuan Pajak Terhutang Pajak Bumi dan Bangunan (SPPT PBB) atau dalam bahasa sehari-hari disebut NJOP saja.Jika nilai NPOP lebih besar dari nilai NJOP maka yang dijadikan sebagai dasar pengenaan PPh dan BPHTB adalah NPOP. Jika nilai NPOP lebih kecil dari NJOP maka yang dijadikan dasar untuk perhitungan $\mathrm{PPh}$ dan BPHTB adalah NJOP.

Alasan yang biasa dikemukakan oleh PPAT yang melakukan pengurusan pajak dari kliennya tersebut adalah karena saat ini semakin marak kasus pemalsuan dalam pembayaran pajak yang dibayarkan sendiri oleh klien-klien PPAT, dalam bentuk pemalsuan bukti pembayaran, palsunya bukti validasi atas pembayaran $\mathrm{PPh}$ maupun BPHTB sampai dengan pemalsuan bukti pembayaran PBB (Irmadevita, 2011).Untuk menghindarkan terjadinya hal-hal di atas, dalam praktek kemudian klien meminta bantuan PPAT untuk membayar pajak (PPh dan/atau BPHTB). Selanjutnya klien mentransfer sejumlah dana atau menyerahkan secara tunai untuk pembayaran pajak. Bahwa selain untuk alasan efisiensi dan keamanan, praktek penitipan pembayaran pajak melalui PPAT dipahami sebagai bagian dari pelayanan PPAT terhadap kliennya.

Secara umum tidak ada peraturan hukum yang melarang PPAT menerima kuasa menyetor pembayaran pajak. Dalam Pasal 3 huruf m Kode Etik PPAT hanya mengatur tentang kewajiban PPAT disebutkan bahwa dalam rangka melaksanakan tugas jabatan (bagi para PPAT serta PPAT pengganti) ataupun dalam kehidupan sehari-hari, setiap PPAT diwajibkan untuk melakukan perbuatan-perbuatan lain yang secara umum disebut sebagai kewajiban untuk ditaati dan dilaksanakan, yang antara lain tercantum dalam:(1) Peraturan Perundangan yang mengatur Jabatan PPAT, (2) isi Sumpah Jabatan, dan (3) Anggaran Dasar, Anggaran Rumah Tangga ataupun keputusan-keputusan lain yang telah ditetapkan oleh Perkumpulan IPPAT, misalnya membayar iuran, membayar uang duka manakala ada seorang PPAT atau mantan PPAT meninggal dunia, atau mentaati ketentuan tentang tarif serta kesepakatan yang dibuat oleh dan mengikat setiap anggota perkumpulan.Ketika tidak ada peraturan hukum yang melarang PPAT menerima kuasa menyetor pajak $\mathrm{PPh} / \mathrm{BPHTB}$, maka secara a contrario hal tersebut diperbolehkan. Namun dengan mengingat munculnya beberapa kasus yang berkaitan dengan resiko penitipan pajak kepada PPAT, terlebih lagi adanya penyalahgunaan kuasa menyetor pajak maka sudah semestinya berkenaan dengan praktek PPAT menerima kuasa menyetor pajak perlu untuk dikaji lebih lanjut.

Dengan demikian ketentuan dalam Pasal 3 huruf m Kode Etik PPAT tersebut tidak menjelaskan tentang hal-hal yang berkaitan dengan penitipan uang pajak oleh klien kepada PPAT. Selain itu tindakan klien menitipkan uang pajak adalah lebih karena unsur kepercayaan kepada PPAT. Pada prakteknya penitipan uang pajak juga tidak pernah diwujudkan dalam bentuk perjanjian penitipan atau pembuatan surat kuasa dari klien kepada PPAT. Dengan demikian hubungan hukum antara klien dengan PPAT dalam hal penitipan uang pajak menjadi tidak jelas. Berdasarkan hal tersebut penulis menganggap perlu untuk melakukan kajian tentangimplikasi yuridis terhadap PPAT yang menerima kuasa menyetor pajak PPH/BPHTB dari wajib pajak. Berdasarkan uraian diatas maka timbul permasalahan mengenai bagaimana legalitas perbuatan menerima kuasa menyetor pajak oleh PPAT selaku pejabat umum dan bagaimana implikasi yuridis terhadap PPAT yang menerima penitipan pajak PPh dan BPHTB dari wajib pajak. Tujuan dari kajian ini adalah untuk menganalisis legalitas perbuatan menerima kuasa menyetor pajak oleh PPAT selaku pejabat umumdan untuk menganalisis implikasi yuridis terhadap PPAT yang menerima penitipan pajak PPh dan BPHTB dari wajib pajak.

\section{METODE}

Jenis kajian yang digunakan dalam tulisan ini adalah penelitian hukum normatif, yaitu merupakankajianhukum yang dilakukan dengan mengkaji bahan-bahan hukum yang berasal dari peraturan perundang-undangan dan berbagai literatur hukum (Soerjono, 2007).Kajian ini dapat 
dikualifikasikan ke dalam jeniskajianhukum normatif, karena Penulis mengkaji apa yang ada dalam peraturan perundang-undangan (law in book) dan literatur hukum yang terkait dengan permasalahan hukum yang dibahas dalam tulisan ini. Kajian mendapati fakta bahwa pada praktek PPAT seringkali dijumpai para pihak penjual dan pembeli meminta bantuan PPAT untuk membayarkan sejumlah pajak penghasilan khususnya PPh Pasal 4 ayat (2) huruf d maupun BPHTB. Dalam ketentuan perpajakan di Indonesia tidak diatur kewenangan PPAT terkait pajak tersebut di atas.Pendekatan yang digunakan dalam menjawab persoalan yang telah dirumuskan adalah dengan menggunakan pendekatan undang-undang (statute approach). Melalui pendekatan ini, peneliti akan menelaah peraturan perundang-undangan yang terkait dengan isu hukum yang sedang dikaji. Pendekatan kasus (case approach), yaitu dilakukan dengan cara melakukan telaah terhadap kasus-kasus yang berkaitan dengan isu yang dihadapi yang telah menjadi putusan pengadilan telah mempunyai kekuatan tetap.

Sinkronisasi antara perundang-undangan dengan kasus yang ada akan membantu peneliti dalam membangun suatu argumentasi hukum dan memecahkan isu yang dihadapi, yaitu kewenangan PPAT dalam membantu kliennya menyetorkan sejumlah pajak terkait pajak-pajak atas pengalihan hak atas tanah dan atau bangunan.Sumber bahan hukum dalam kajian hukum normatif berupa bahan hukum, baik bahan hukum primer, sekunder, dan tersier. Bahan hukum primer mempunyai karakter otoritatif yaitu memiliki kekuatan mengikat yang terdiri atas berbagai peraturan perundangundangan, bahan hukum sekunder yang digunakan mempunyai karakter hukum ilmiah yang merupakan hasil karya dan penelitian dari kalangan hukum seperti buku-buku, disertasi, jurnal ilmiah dan hasil penelitian lain dan bahan hukum tersier yakni bahan yang memberikan petunjuk maupun penjelasan dari bahan hukum primer dan sekunder contohnya kamus hukum dan ensiklopedia

\section{HASIL DAN PEMBAHASAN}

\section{Legalitas Perbuatan Menerima Kuasa menyetor Pajak oleh PPAT Selaku Pejabat Publik}

Setiap perjanjian yang bermaksud memindahkan hak atas tanah harus dibuktikan dengan akta yang dibuat oleh dan dihadapan pejabat yang ditunjuk oleh Menteri yaitu Pejabat Pembuat Akta Tanah (PPAT). Peralihan hak atas tanah yang tidak dilakukan dihadapan PPAT memang tidak ada sanksinya bagi para pihak, namun para pihak tidak akan dapat mendaftarkan peralihan haknya sehingga tidak akan mendapatkan sertifikat atas namanya. Oleh karena itu, jalan yang dapat ditempuh adalah dengan mengulangi prosedur peralihan haknya dihadapan PPAT. Tetapi cara ini tergantung dari kemauan para pihak yang bersangkutan.

Berdasarkan ketentuan Pasal 37 Peraturan Pemerintah Nomor 24 Tahun 1997 tentang Pendaftaran Tanah disebutkan bahwa Peralihan hak atas tanah dan hak milik atas satuan rumah susun melalui jual-beli, tukar-menukar, hibah, pemasukan dalam perusahaan dan perbuatan hukum pemindahan hak lainnya kecuali pemindahan hak melalui lelang hanya dapat didaftarkan jika dibuktikan dengan akta yang dibuat oleh Pejabat Pembuat Akta Tanah (PPAT) yang berwenang menurut ketentuan peraturan perundang-undangan yang berlaku. Pembuatan akta oleh PPAT dalam peralihan hak atas tanah dihadiri oleh para pihak yang melakukan perbuatan hukum dan dihadiri juga oleh sekurang-kurangnya dua orang saksi yang memenuhi syarat yang telah ditentukan.

Peralihan hak adalah suatu perbuatan hukum yang bertujuan memindahkan hak dari suatu pihak ke pihak lain.Peralihan hak atas tanah merupakan suatu proses perubahan data yuridis hak atas tanah yang telah terdaftar. Peralihan hak ini dapat terjadi karena dua hal:

a. Peristiwa hukum.

Peristiwa hukum adalah peristiwa-peristiwa kemasyarakatan yang timbul dari hubungan antar anggota masyarakat yang oleh hukum diberikan akibat-akibat hukum. Peralihank hak karena persitiwa hukum terjadi salah satunyaapabila terdapat peristiwa terbukanya boedel waris. Secara yuridis, harta warisan telah beralih pada saat kematian pewaris. Namun demikian peralihannya secara administratif baru terjadi pada saat didaftarkan. Pada hakekatnya pendaftaran beralihnya hak ini merupakan tindakan administratif atas hartanya sendiri. Oleh karena itu, tidak diperlukan akta yang membuktikan adanya suatu perbuatan hukum peralihan hak, melainkan cukup dengan keterangan yang 
menyatakan bahwa yang bersangkutan adalah satu-satunya ahli waris dari pemegang hak.

b. Perbuatan hukum.

Terjadi apabila terdapat perbuatan hukum berikut: (a) jual beli, (b) tukar menukar, (c) hibah, (d) pemasukan dalam perusahaan (inbreng), (e) lelang, (f) pemberian hak guna bangunan/hak pakai atas tanah hak milik, $(\mathrm{g})$ pemberian hak tanggungan, (h) pemberian kuasa pembebanan hak tanggungan.

Sebelum melakukan peralihan hak atas tanah, antara kedua pihak terlebih dahulu melakukan perjanjian atau kesepakatan mengenai bidang tanah yangakan dialihkan haknya tersebut. Setiap peralihan hak atas tanah, yang terjadi karena adanya perbuatan hukum(kecuali lelang) harus dibuat di hadapan PPAT. Agar peralihan hak atas tanah dapat terselenggara secara benar, maka seorang PPAT yang akan membuat peralihan hak atas tanah harus memastikan kebenaran mengenai hak atas tanah tersebut serta memastikan kecakapan dan kewenangan bertindak dari mereka yang akan mengalihkan dan menerima pengalihan hak atas tanah tersebut.

\section{Hubungan Hukum PPAT dengan Para Pihak}

Ketika para pihak datang ke PPAT agar perbuatan hukumnya diformulasikan ke dalam akta otentik sesuai dengan kewenangan PPAT, dan kemudian PPAT membuatkan akta atas permintaan atau keinginan para pihak tersebut, maka dalam hal ini memberikan landasan kepada PPAT dan para pihak bahwa telah terjadi suatu hubungan hukum. Oleh karena itu, PPAT harus menjamin bahwa akta yang dibuat tersebut telah sesuai menurut aturan hukum yang telah ditentukan sehingga kepentingan para pihak terlindungi dengan akta tersebut. Adanya hubungan hukum yang seperti itu maka perlu ditentukan kedudukan hubungan hukum tersebut yang merupakan awal dari tanggung gugat (Marthalena, 1985).

Penentuan hubungan hukum antara PPAT dan para pihak perlu untuk dilakukan sejak awal untuk memudahkan dalam menentukan bentuk tanggungjawab yang harus dilaksanakan oleh PPAT jika di kemudian hari para pihak merasa dirugikan oleh tindakan PPAT yang terkait dengan pembuatan akta yang bersangkutan. Hubungan hukum tersebut dapat berlandaskan pada salah satu dari hal-hal berikut:

\section{a. Wanprestasi; atau}

Hubungan hukum antara para pihak dengan PPAT dapat dikualifikasikan dalam bentuk sebuah wanprestasi apabila terjadi hubungan hukum secara kontraktual, misalnya para pihak memberi kuasa untuk melakukan suatu pekerjaan tertentu untuk dan atas nama pemberi kuasa. Para pihak datang kepada PPAT karena keinginan para pihak sendiri, dan memang pada dasarnya semua PPAT terbuka untuk siapa saja.

Para pihak ini datang bukan karena diminta oleh PPAT dan ketika para pihak datang kepada PPAT tidaklah perlu untuk dibuat suatu perjanjian terlebih dahulu sebelumnya dengan PPAT yang bersangkutan bahwa para pihak tersebut ingin membuat sebuah akta otentik karena memang sudah jelas itulah tujuan mereka datang kepada PPAT. Tidak adanya perjanjian baik tertulis maupun tidak tertulis yang dinyatakan secara tegas antara PPAT dengan para pihak untuk membuat akta yang diinginkan menjadikan PPAT tidak dapat dimintakan pertanggungjawaban dengan alasan telah melakukan wanprestasi, karena tidak ada unsur-unsur wanprestasi di dalamnya.

\section{b. Perbuatan melawan hukum (onrechtmati- gedaad; atau}

Inti dari suatu perbuatan melawan hukum adalah tidak adanya hubungan kontraktual antara satu pihak dengan pihak lainnya. Perbuatan melawan hukum dapat terjadi jika salah satu pihak menimbulkan kerugian bagi pihak lainnya, walaupun dilakukan tanpa sengaja sekalipun. Dalam prakteknya, PPAT melakukan suatu pekerjaan berdasarkan kewenangannya atau dalam ruang lingkup tugas dan jabatannya. Para pihak datang atas kesadaran sendiri kepada PPAT untuk mendapatkan pelayanan yang kemudian dituangkan ke dalam bentuk akta otentik sesuai aturan hukum yang berlaku. PPAT tidak mungkin membuatkan akta tanpa ada permintaan dari siapapun. Sepanjang PPAT melaksanakan tugas dan jabatannya sesuai aturan yang ada, dan telah memenuhi semua tatacara dan persyaratan dalam pembuatan akta, dan akta yang bersangkutan telah pula sesuai dengan keinginan para pihak yang menghadap PPAT, maka tuntutan dan tanggungjawab karena alasan PPAT telah melakukan perbuatan melawan hukum berdasarkan Pasal 1365 KUHPerdata tidak dapat dilakukan. 


\section{c. Mewakili orang lain tanpa kuasa (zaakwaarneming); atau}

Subjek hukum yang datang kepada PPAT didasari adanya suatu keperluan dan keinginan sendiri, PPAT tidak melakukan suatu pekerjaan atau membuat akta tanpa ada permintaan dari para pihak, sehingga tidak bisa menuntut PPAT dengan tuntutan telah mewakili para pihak tanpa adanya kuasa (zaakwarneming) Pasal 1354 KUHPerdata.

\section{d. Pemberian kuasa (lastgeving); atau e. Perjanjian untuk melakukan pekerjaan tertentu; atau \\ f. Persetujuan perburuhan.}

Inti dari pemberian kuasa adalah terdapat suatu persetujuan yang berisikan pemberian kekuasaan kepada orang lain yang menerimanya untuk melaksanakan sesuatu atas nama orang yang memberikan kuasa (Pasal 1792 KUHPerdata). Jika tidak ada pemberian kuasa, tidak ada persetujuan atau saling mengikatkan diri antara para pihak dengan PPAT untuk melakukan pekerjaan-pekerjaan tertentu, maka hubungan hukum antara PPAT dan para pihak bukan merupakan hubungan hukum berupa pemberian kuasa (lastgeving), bukan juga berupa perjanjian untuk menerima atau melakukan pekerjaan tertentu persetujuan perburuhan dan pemborongan pekerjaan (Pasal 1601 KUHPerdata) ataupun persetujuan perburuhan yang melakukan pekerjaan di bawah perintah orang lain(Pasal 1601 d KUHPerdata), para pihak yang mengalami kerugian di kemudian hari tidak dapat menuntut PPAT atas dasar-dasar tersebut karena memang tidak dikuasakan atau diperjanjikan sebelumnya, lagipula hal-hal tersebut juga tidak diperlukan, seperti yang telah dijelaskan di atas.

Berdasarkan hal-hal tersebut, faktanya ternyata sejak awal pun hubungan hukum yang terjadi antara PPAT dan para pihak tidak dapat dikonstruksikan, ditentukan atau dipastikan ke dalam bentuk wanprestasi atau perbuatan melawan hukum (onrechtmatigedaad) atau mewakili orang lain tanpa kuasa (zaakwaarneming), atau pemberian kuasa (lastgeving), atau perjanjian untuk melakukan pekerjaanpekerjaan tertentu ataupun persetujuan perburuhan yang membuatnya dapat dijadikan dasar untuk menuntut PPAT, baik tuntutan berupa penggantian biaya, ganti rugi, dan/atau bunga. Konstruksi seperti itu tidak dapat dipastikan di awal secara langsung terhadap PPAT sebab tidak ada syarat yang dipenuhi, seperti: (a) dda perjanjian secara tertulis atau kuasa atau untuk melakukan pekerjaan tertentu, (b) ada hak-hak para pihak atau salah satu pihak yang dilanggar oleh PPAT, (c) PPAT tidak mempunyai alasan untuk menerima perintah melakukan suatu pekerjaan; dan (d) ada kesukarelaan dari PPAT untuk membuat akta, tanpa ada permintaan dari para pihak.

Hubungan hukum yang terjadi antara PPAT dan para pihak adalah hubungan hukum yang khas, dengan karakter: (a) tidak perlu dibuat suatu perjanjian baik lisan maupun tertulis dalam bentuk pemberian kuasa untuk membuat akta atau untuk melakukan pekerjaan-pekerjaan tertentu, (b) mereka yang datang ke hadapan PPAT telah mengetahui bahwa PPAT mempunyai kemampuan untuk membantu memformulasikan keinginan para pihak secara tertulis dalam bentuk akta otentik; (c) hasil akhir dari tindakan PPAT berdasarkan pada kewenangan PPAT yang berasal dari permintaan atau keinginan para pihak sendiri; dan (d) PPAT bukan pihak dalam akta yang bersangkutan.

Jadi, hubungan hukum antara PPAT dengan para pihak adalah hubungan antara pejabat umum yang memiliki kewenangan tertentu dengan masyarakat yang memiliki kebutuhan khusus berkaitan dengan kewenangan tertentu yang dimiliki oleh pejabat umum tersebut.Dapat dikatakan bahwa hubungan hukum yang terjadi antara keduanya adalah suatu bentuk pelayanan umum untuk membuat akta otentik yang berkaitan dengan bidang pertanahan.

\section{Kualitas Legalitas PPAT dalam Memberikan Pelayanan Publik}

PPAT sebagai seorang Pejabat Umum yang pengertiannya adalah pejabat yang diserahi tugas untuk melayani kepentingan masyarakat, secara umum memiliki kualifikasi untuk memberikan pelayanan publik. Pelayanan Publik yang berwenang untuk dilakukan oleh PPAT secara khusus adalah membuat akta otentik yang dapat dijadikan sebagai bukti telah dilakukannya perbuatan hukum tertentu mengenai hak atas tanah atau Hak Milik Atas Satuan Rumah Susun, dan akan dijadikan dasar bagi pendaftaran perubahan data pendaftaran tanah yang diakibatkan oleh perbuatan hukum itu. Perbuatan hukum yang dimaksud meliputi jual beli, tukar menukar, hibah, pemasukan ke dalam perusahaan 
(inbreng), pembagian hak bersama, pemberian Hak Guna Bangunan/Hak Pakai atas Tanah Hak Milik, pemberian Hak Tanggungan, serta pemberian Kuasa membebankan Hak Tanggungan.

Berdasarkan hal tersebut, kesimpulannya posisi PPAT dalam hal membayarkan kuasa menyetor pajak dari kliennya adalah sebagai bagian dari pelayanan PPAT atau bisa juga disebut pelayanan tambahan dari rangkaian pelayanan utama yang menjadi kewenangan PPAT yakni membuat akta otentik. Belum ada legalitas yang memperbolehkan dan/atau melarang untuk melakukan perbuatan tersebut, hanya berdasar pada kebiasaan saja.

Kebiasaan penitipan pembayaran pajak ini sesungguhnya berangkat dari itikad baik kedua pihak. Klien bersedia untuk membayar pajak, dan PPAT bersedia membantu pengurusannya atas dasar efisiensi dan keamanan. Oleh karena itu kebiasaan tersebut perlu diatur secara tegas agar ada payung hukumnya dan memberikan jaminan perlindungan hukum bagi pihak-pihak terkait.

\section{Implikasi Yuridis terhadap PPAT yang Menerima Penitipan Pajak PPh dan BPHTB Dari Wajib Pajak}

Suatu keabsahan akan sesuatu idealnya harus sesuai/berdasarkan pada suatu hukum. Dalam kriteria legalitas sebagai dasar keabsahan dari suatu kewenangan diistilahkan sebagai "Regressus ad Invinitum" (mundur tanpa akhir), sebab suatu hukum positif yang mendasari keabsahan dari sebuah kewenangan atau kekuasaan idealnya harus berdasarkan pada suatu hukum positif juga. Pandangan ini dapat dikaitkan sejalan dengan Stufenbau Theorie dari Hans Kelsen yang menyebutkan bahwa keabsahan norma hukum harus didasarkan pada norma yang lebih tinggi, sehingga secara hipotesis keabsahan sebuah norma hukum harus bersumber pada "norma dasar" (grundnorm).

Salah satu dasar dari wewenang Pemerintah adalah Asas Legalitas. Sebagai konsekuensi dari Negara hukum, wajib adanya jaminan bagi administrasi negara sebagai alat perlengkapan negara untuk dapat menjalankan Pemerintahan, sedangkan warga negara memiliki hak dan kewajiban untuk mendapat jaminan perlindungan. Oleh karena itu kekuasaan Pemerintah tidak dapat lepas dari perkembangan asas legalitas yang artinya setiap tindakan Pemerintah harus berdasarkan pada undang-undang.

Berdasarkan pembahasan sebelumnya, berkaitan dengan tindakan PPAT menerima kuasa menyetor pembayaran pajak dari kliennya, diketahui bahwa belum ada legalitas atas perbuatan tersebut, hanya berdasarkan pada kebiasaan saja. Kebiasaan ialah perbuatan manusia yang tetap dilakukan berulang-ulang dalam hal yang sama. Apabila suatu kebiasaan tertentu diterima oleh masyarakat dan kebiasaan itu selalu berulang-ulang dilakukan sedemikian rupa, sehingga tindakan yang berlawanan dengan kebiasaan itu dirasakan sebagai pelanggaran perasaan hukum, maka dengan demikian timbul suatu kebiasaan hukum, yang oleh pergaulan dipandang sebagai hukum (C.S.T. Kansil, 1989).Dalam hal perbuatan PPAT menerima pembayaran kuasa menyetor pajak dari kliennya sudah menjadi kebiasaan karena dilakukan berulang-ulang, meskipun jika ada PPAT yang tidak berkenan untuk melakukan perbuatan tersebut pun tidak dapat dikatakan sebagai suatu bentuk pelanggaran hukum namun terhadap PPAT yang melakukan hal tersebut sudah dipandang sebagai hal yang lumrah oleh masyarakat, khususnya mereka yang menggunakan jasa dari PPAT.

Perlindungan hukum merupakan perlindungan yang diberikan terhadap subjek hukum dalam bentuk perangkat hukum baik, yang bersifat preventif maupun yang bersifat represif, baik yang tertulis maupun tidak tertulis. Perlindungan hukum merupakan suatu gambaran dari fungsi hukum, yaitu konsep di mana hukum tersebut dapat memberikan suatu keadilan, ketertiban, kepastian, kemanfaatan dan kedamaian.

Pembahasan tentang legalitas sebuah aturan tidak bisa terlepas dari keabsahan, sebab legalitas merupakan dasar keabsahan dari sebuah kewenangan. Keabsahan hukum (legal validity) adalah teori yang mengajarkan bagaimana dan apa syarat-syaratnya agar suatu kaidah hukum menjadi "sah" (valid) berlakunya, sehingga dapat diberlakukan kepada masyarakat.

Agar hukum dapat menjadi "sah", maka hukum haruslah dapat diberlakukan terhadap masyarakat, maka suatu kaidah hukum haruslah merupakan hukum yang valid. Dari keadaan tersebut barulah kemudian timbul konsep-konsep tentang perintah (command), larangan (forbidden), kewenangan (authorized), paksaan (force) dan kewajiban (obligation). Namun demikian, 
suatu kaidah hukum yang "valid", belum tentu merupakan suatu kaidah hukum yang "efektif", dalam hal ini "keabsahan" suatu norma merupakan hal yang tergolong ke dalam "yang seharusnya" (das sollen), sedangkan "efektifitas" suatu norma, merupakan "sesuatu dalam kenyataan" (das sein).

Berdasarkan uraian tersebut, dapat dikatakan bahwa keabsahan suatu aturan hukum diperlukan untuk mensahkan aturan hukum yang mempunyai fungsi untuk mengetahui: (a) eksistensi suatu aturan hukum, (b) tingkat penerimaan masyarakat, (c) tingkat kesadaran hukum dari penegak hukum terhadap kaidah hukum yang bersangkutan, (c) apakah aturan hukum tersebut memang dimaksudkan sebagai aturan yang mengikat secara hukum, (d) akibat hukumnya jika suatu aturan hukum tidak diikuti oleh masyarakat, (e) perlunya dibuat suatu aturan hukum yang baru, yang mengatur berbagai persoalan manusia; (f) ikatan-ikatan non-hukum dari suatu aturan hukum.

Berdasarkan hal tersebut, meskipun perbuatan PPAT menerima kuasa menyetor pembayaran pajak dari kliennya belum memiliki legalitas hukum namun pelaksanaannya masih termasuk dalam kategori sah sebab perbuatan tersebut berangkat dari adat kebiasaan yang berlaku selama ini dan diterima oleh masyarakat. Selama belum ada aturan hukum untuk mewujudkan legalitas dari perbuatan ini maka selama itu pula kebiasaan ini akan terus berlanjut, walaupun tidak ada jaminan perlindungan hukum atas perbuatan ini tetapi selama tidak menimbulkan kerugian bagi siapapun maka dianggap tidak masalah.

\section{SIMPULAN}

1. Legalitas perbuatan menerima kuasa menyetor pajak oleh PPAT selaku pejabat publik sesungguhnya masih belum ada, dengan kata lain belum dibentuk suatu aturan pasti yang mengatur tentang perbuatan menerima kuasa menyetor pajak oleh PPAT yang seharusnya dibayarkan sendiri oleh para pihak selaku wajib pajak. Selama ini hanya berdasarkan pada kebiasaan saja dan berpegang pada itikad baik dari PPAT maupun para pihak. Perbuatan tersebut dianggap sebagai bagian dari pelayanan PPAT atau sebagai pelayanan tambahan dari rangkaian pelayanan utama yang menjadi kewenangan PPAT yakni membuat akta otentik. Dimungkinkan juga legalitas perbuatan tersebut adalah berupa pemberian kuasa apabila didahului oleh pmberian kuasa untuk pembayaran pajak dari klien kepada PPAT.

2. Implikasi yuridis terhadap PPAT yang menerima penitipan pajak PPh dan BPHTB dari wajib pajak adalah:

a. Perbuatan PPAT menerima kuasa menyetor pembayaran pajak dari kliennya belum memiliki legalitas hukum namun pelaksanaannya masih termasuk dalam kategori sah sebab perbuatan tersebut berangkat dari kebiasaan yang berlaku selama ini dan diterima oleh masyarakat. Selama belum ada aturan hukum untuk mewujudkan legalitas dari perbuatan ini maka selama itu pula kebiasaan ini akan terus berlanjut, walaupun tidak ada jaminan perlindungan hukum atas perbuatan ini tetapi selama tidak menimbulkan kerugian bagi siapapun maka dianggap tidak masalah.

b. PPAT yang melakukan wanprestasi wajib bertanggungjawab atas segala biaya, kerugian, dan bunga yang timbul dari tidak dilaksanakannya prestasi yang diberikan kepadanya. PPAT juga wajib bertanggungjawab atas segala perbuatan yang dilakukan dengan sengaja dan kelalaian-kelalaian yang dilakukan dalam memenuhi prestasi.PPAT yang memberikan kuasa kepada karyawannya untuk membayarkan pajak bertanggung jawab terhadap segala akibat yang terjadi apabila terdapat kelalaian dari karayawannya.

c. PPAT yang melakukan perbuatan melawan hukum dalam ranah Hukum Perdata terkait kuasa menyetor pembayaran pajak kliennya bertanggungjawab atas penggantian biaya, ganti rugi dan/atau bunga, asalkan terlebih dahulu harus dapat dibuktikan adanya: (a) kerugian, (b) terdapat hubungan kausal antara derita dengan pelanggaran atau kelalaian dari PPAT, (c) pelanggaran atau kelalaian tersebut disebabkan kesalahan yang dapat dipertanggungjawabkan kepada PPAT yang bersangkutan.

d. PPAT yang melakukan perbuatan melawan hukum dalam ranah Hukum Pidana terkait kuasa menyetor pembayaran pajak kliennya yang paling mungkin terjadi adalah tindak pidana penggelapan dalam jabatan. 


\section{DAFTAR RUJUKAN}

Agustina Lusiana Elisabet Lumbanbatu, 2011, Analisis Hukum Atas Perbuatan Oknum Notaris yang Menerima Penitipan Pembayaran Bea Perolehan Hak Atas Tanah dan Bangunan (BPHTB): Studi Putusan Pengadilan Negeri Medan No. 2601/Pid.B/2003/PN.Mdn, Tesis Program Magister Kenotariatan, Universitas Sumatera Utara.

C.S.T. Kansil, 1989, Pengantar Ilmu Hukum dan Tata Hukum Indonesia, Balai Pustaka, Jakarta.

Devita, Irma. 2011. Waspadalah para notaris/ ppat dalam melakukan pembayaran pajak. Online. Diakses tanggal 10 Januari 2017. http://irmadevita.com/2011/waspadalah-para-notarisppat-dalam-melakukanpembayaran-pajak/.

Marthalena Pohan, 1985, Tanggung Gugat Advocaat, Dokter, dan Notaris, Bina Ilmu, Surabaya.

Republik Indonesia. Kitab Undang-Undang Hukum Perdata.

Republik Indonesia. 1960. Undang-Undang Nomor 5 Tahun 1960 tentang Peraturan Dasar Pokok-Pokok Agraria.
Republik Indonesia. 1996. Undang-Undang Nomor 4 Tahun 1996 tentang Hak Tanggungan atas Tanah beserta BendaBenda yang Terkait dengan Tanah.

Republik Indonesia. 1997. Peraturan Pemerintah Nomor 24 Tahun 1997 tentang Pendaftaran Tanah.

Republik Indonesia. 1998. Peraturan Pemerintah Nomor 37 Tahun 1998 tentang Peraturan Jabatan Pejabat Pembuat Akta Tanah.

Republik Indonesia. 2006. Peraturan Kepala Badan Pertanahan Nasional Nomor 1 Tahun 2006 tentang Ketentuan Pelaksanaan Peraturan Pemerintah Nomor 37 Tahun 1998 tentang Peraturan Jabatan Pejabat Pembuat Akta Tanah.

Soerjono Soekanto dan Sri Mamudji, 2007, Penelitian Hukum Normatif: Suatu Tinjauan Singkat, RajaGrafindo Persada, Jakarta. 